Research Article

\title{
Investigation of Heavy Metal Effects on the Anaerobic Co-Digestion Process of Waste Activated Sludge and Septic Tank Sludge
}

\author{
Quang-Minh Nguyen, ${ }^{1,2}$ Duy-Cam Bui, ${ }^{1}$ Thao Phuong $\left(\mathbb{D},{ }^{1}\right.$ Van-Huong Doan, \\ Thi-Nham Nguyen $\mathbb{D}^{1},{ }^{1}$ Minh-Viet Nguyen $\mathbb{D}^{1},{ }^{1}$ Thien-Hien Tran, ${ }^{3}$ and Quang-Trung Do $\mathbb{D}^{1}$ \\ ${ }^{1}$ VNU University of Science, Vietnam National University, Hanoi, 334 Nguyen Trai, Thanh Xuan District, Hanoi, Vietnam \\ ${ }^{2}$ Hai Phong University, 171 Phan Dang Luu, Kien An District, Hai Phong, Vietnam \\ ${ }^{3}$ Center of Excellence for Green Energy and Environmental Nanomaterials (CE@GrEEN), Nguyen Tat Thanh University, \\ Ho Chi Minh City, Vietnam
}

Correspondence should be addressed to Quang-Trung Do; doquangtrung@hus.edu.vn

Received 15 March 2019; Revised 23 September 2019; Accepted 31 October 2019; Published 1 December 2019

Academic Editor: Doraiswami Ramkrishna

Copyright (C) 2019 Quang-Minh Nguyen et al. This is an open access article distributed under the Creative Commons Attribution License, which permits unrestricted use, distribution, and reproduction in any medium, provided the original work is properly cited.

\begin{abstract}
The effect of copper, zinc, chromium, and lead on the anaerobic co-digestion of waste activated sludge and septic tank sludge in Hanoi was studied in the fermentation tests by investigating the substrate degradation, biogas production, and process stability at the mesophilic fermentation. The tested heavy metals were in a range of concentrations between 19 and $80 \mathrm{ppm}$. After the anaerobic tests, the TS, VS, and COD removal efficiency was $4.12 \%, 9.01 \%$, and $23.78 \%$ for the $\mathrm{Cu}(\mathrm{II})$ added sample. Similarly, the efficiencies of the $\mathrm{Zn}(\mathrm{II})$ sample were $1.71 \%, 13.87 \%$, and $16.1 \%$ and $\mathrm{Cr}(\mathrm{VI})$ efficiencies were $15.28 \%$, $6.6 \%$, and $18.65 \%$, while the $\mathrm{TS}, \mathrm{VS}$, and COD removal efficiency of the $\mathrm{Pb}$ (II) added sample was recorded at $16.1 \%, 17.66 \%$, and $16.03 \%$ at the concentration of $80 \mathrm{ppm}$, respectively. Therefore, the biogas yield also decreased by $36.33 \%, 31.64 \%, 31.64 \%$, and 30.60\% for $\mathrm{Cu}(\mathrm{II}), \mathrm{Zn}$ (II), $\mathrm{Cr}$ (VI), and $\mathrm{Pb}(\mathrm{II})$ at the concentration of $80 \mathrm{ppm}$, compared to the raw sample, respectively. These results indicated that $\mathrm{Cu}$ (II) had more inhibiting effect on the anaerobic digestion of the sludge mixture than $\mathrm{Zn}(\mathrm{II}), \mathrm{Cr}(\mathrm{VI})$, and $\mathrm{Pb}(\mathrm{II})$. The relative toxicity of these heavy metals to the co-digestion process was as follows: $\mathrm{Cu}$ (the most toxic) $>\mathrm{Zn}>\mathrm{Cr}>\mathrm{Pb}$ (the least toxic). The anaerobic codigestion process was inhibited at high heavy metal concentration, which resulted in decreased removal of organic substances and produced biogas.
\end{abstract}

\section{Introduction}

Anaerobic process of waste activated sludge and septic tank sludge is a complex microbiological process involving various types of anaerobic and facultative bacteria. This way of sludge treatment involves degradation and stabilization of organic matter. The microorganisms are susceptible to heavy metals due to some specific physicochemical parameters, including the electronegativity, Pearson's softness index, the standard reduction potential, the solubility product of the metal-sulfide complex, the electron density, and the covalent index $[1,2]$.
The heavy metals accumulated in municipal sludge from various sources such as the use of metallic chemicals, pipeline corrosion, the washing machine equipment process, bleaching, and neutralization [3, 4]. Heavy metals such as $\mathrm{Cu}, \mathrm{Zn}, \mathrm{Pb}, \mathrm{Hg}, \mathrm{Cr}, \mathrm{Cd}, \mathrm{Fe}, \mathrm{Ni}, \mathrm{Co}$, and $\mathrm{Mo}$ are often found in waste sludge at high concentrations. Some metals at low concentrations, such as $\mathrm{Ni}, \mathrm{Co}, \mathrm{Zn}$, and $\mathrm{Cu}$, are required for the activation or functioning of many enzymes and coenzymes in anaerobic digestion; however, at high concentration, can lead to toxic or inhibitory [5-8]. Despite the fact that the above phenomena have been studied quite extensively, the researchers have not clearly concluded whether 
the presence of particular heavy metals inhibits or stimulates microbial growth. An even greater ambiguity exists regarding the establishment of growth-stimulating and toxic doses of heavy metals [9].

The effects of heavy metals on the anaerobic digestion process have been widely studied. In general, the methane yield from the anaerobic digestion of granular sludge decreased with increasing heavy metal concentrations above $32 \mathrm{ppm}$ [10]. Other studies revealed that the inhibition effect of toxic was quite different with the pattern of $\mathrm{Zn}>\mathrm{Cr}>\mathrm{Ni} \approx \mathrm{Cd}[10]$ or $\mathrm{Cu}$ (the most toxic) $>\mathrm{Ni} \sim \mathrm{Zn}>\mathrm{Pb}$ (the least toxic) [11] or $\mathrm{Hg}>\mathrm{Cd}>\mathrm{Cr}$ (III) [12].

Until now, there are no reports that have been performed to assess the effect of four metals $(\mathrm{Cu}, \mathrm{Zn}, \mathrm{Cr}$, and $\mathrm{Pb})$ on coanaerobic processes of waste activated sludge and septic tank sludge. This study aims to investigate the effects of metals on co-anaerobic processes of waste activated sludge and septic tank sludge; this eventually specifies the inhibitory effect of these metals on the anaerobic stabilization of sludge.

\section{Materials and Methods}

2.1. Sludge Sampling. Waste activated sludge (WAS) samples were obtained from the Kim Lien wastewater treatment plant, with a capacity of $3,700 \mathrm{~m}^{3} /$ day. Wastewater from $4.6 \mathrm{~km}^{2} \mathrm{Kim}$ Lien area was treated before discharging into the Lu river. The sources of wastewater include households, hotels, hospitals, metalwork, and markets.

Septic tank sludge (STS) samples were taken at the septic tank sludge treatment station, Urenco 7, Hanoi, mainly collected from public toilets, households, and agencies of Hanoi, with the quantity of $50-60 \mathrm{~m}^{3} \cdot$ day $^{-1}$.

2.2. Chemicals and the Biogas Reactor. Chemicals $\left(\mathrm{Cu}\left(\mathrm{NO}_{3}\right)_{2}\right.$, $\mathrm{Pb}\left(\mathrm{NO}_{3}\right)_{2}, \mathrm{Zn}\left(\mathrm{NO}_{3}\right)_{2}$, and $\left.\mathrm{K}_{2} \mathrm{Cr}_{2} \mathrm{O}_{7}\right)$ were obtained from Merck Chemicals (Darmstadt, Germany).

The biogas reactor was installed by the following process: the thirty-two anaerobic batch tests of $1.0 \mathrm{~L}$ volume (Figure 1). The volume of each reactor is $1.0 \mathrm{~L}$ and can only be filled up to $0.7 \mathrm{~L}$ for the produced biogas. The batch reactor was attached to the corresponding gas volume (note the numbering), and the top tidily was closed. Finally, the pipe connection for gas sampling was closed with the screw tab.

2.3. Experimental Design. Figure 2 shows the experiment procedure. All tests were conducted in 1-liter glass bottles of self-designed batch digesters. Each anaerobic digestion reactor contained $120 \mathrm{~mL}$ WAS and $480 \mathrm{~mL}$ STS and was tightly closed with a screw cap and rubber septum. The WAS/STS ratios of $20: 80$ (\% of total feedstock measured as wet weight (w/w)) (sample SBS) $[13,14]$ were tested under the mesophilic condition for 20 days with the original total solid concentration of $7.35 \%$. The initial sludge samples were analyzed for volatile solids $(\mathrm{VS}=83.14 \%)$, total solids ( $\mathrm{TS}=6.15 \% \pm 0.17 \%), \mathrm{pH}$ $(\mathrm{pH}=7.52 \pm 0.56), \mathrm{COD}\left(6863.6 \pm 75.3 \mathrm{mg} \mathrm{O} \cdot \mathrm{L}^{-1}\right)$, and the content of lead $(0.688 \pm 0.003 \mathrm{ppm})$, chromium $(0.4676 \pm$ $0.001 \mathrm{ppm})$, zinc $(9.4296 \pm 0.02 \mathrm{ppm})$, and copper $(1.3086 \pm$ 0.015 ppm), respectively.
The $\mathrm{Cu}(\mathrm{II}), \mathrm{Zn}(\mathrm{II}), \mathrm{Pb}(\mathrm{II})$, or $\mathrm{Cr}(\mathrm{VI})$ salts were dissolved in distilled water and then were added to the reactors at the concentration of $19 \mathrm{ppm}, 40 \mathrm{ppm}, 60 \mathrm{ppm}$, and $80 \mathrm{ppm}$, respectively. The compaction capacity of the reactors reached 0.62 liters. Each sample was mixed to obtain a homogeneous mixture for 3-5 min before the anaerobic digestion process. All reactors were shaken manually for $1 \mathrm{~min} /$ day during the anaerobic digestion process. The experiments were performed, repeated three times, and took an average result. The sample labels are shown in Table 1.

2.4. Determination of Total Solids, Volatile Solids, and Chemical Oxygen Demand. The total solids (TS), volatile solids (VS), and chemical oxygen demand (COD) were determined in accordance with APHA Standard Methods. The TS was determined by drying at $105^{\circ} \mathrm{C}$ with a universal oven (Model UN55, Memmert, Germany) for $24 \mathrm{~h}$ under the SMEWW 2540.B: 2000 method. The volatile solids (VS) were determined by calcining dry samples in ceramic cups at $550^{\circ} \mathrm{C}$ with a furnace (Model B180, Nabertherm, Germany) for 8 hours according to the SMEWW 2540.E: 2000 method. The COD was determined by dichromat and photometric measurements at $605 \mathrm{~nm}$ with a spectrophotometer (Model UH-5300, Hitachi, Tokyo, Japan) according to SMEWW 5220.C: 2012 method. The volume of the produced biogas was measured by using the water displacement method each day throughout the anaerobic digestion process.

\section{Results and Discussion}

3.1. Effects of Copper, Lead, Chromium, and Zinc for TS and VS Removal. Figure 3 and Table 2 show the effects of copper, zinc, chromium, and lead on the anaerobic digestion of WAS and STS through the change of TS and VS. It can be seen that the TS and VS had a tendency of reduction as increasing the testing time. The decrease in VS may be due to the partial decomposition of organic matter in sludge. This reduction corresponds to the reduction and stability of sludge, as well as the performance of anaerobic digestion [15]. In addition, the scaling of TS was down also due to the incomplete removing by biogas formation and then the remaining fraction was detached in the digestate into the soluble organic compounds [16]. The removal efficiency of TS and VS was gradually increased over the course of the experiment.

The general trend occurred when the concentrations of four metals increased; the TS and VS of samples were decreased in the anaerobic process. The TS and VS of SBS samples significantly decreased from $6.15 \% \pm 0.17 \%$ to $3.68 \% \pm 0.1 \%$ and $83.14 \% \pm 1.87 \%$ to $48.23 \% \pm 1.08 \%$, respectively. The TS and VS removal efficiency of the ECS1, ECS2, ECS3, and ECS4 samples was decreased with the increasing of $\mathrm{Cu}$ (II) concentration. The ECS4 sample ( $\mathrm{Cu}$ (II) concentration $=80 \mathrm{ppm}$ ) showed the lowest digestion efficiency compared to other samples. The TS and VS of the ECS4 sample were $5.86 \% \pm 0.16 \%$ (removal efficiency $=$ $4.12 \%$ ) and $75.65 \% \pm 1.7 \%$ (removal efficiency $=9.01 \%$ ), 


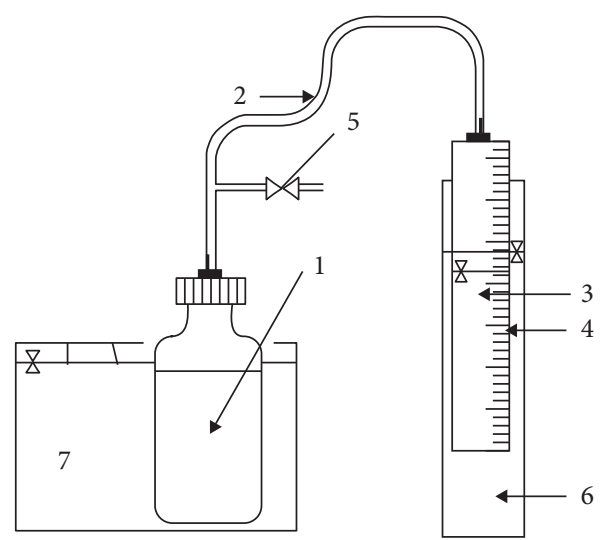

(a)

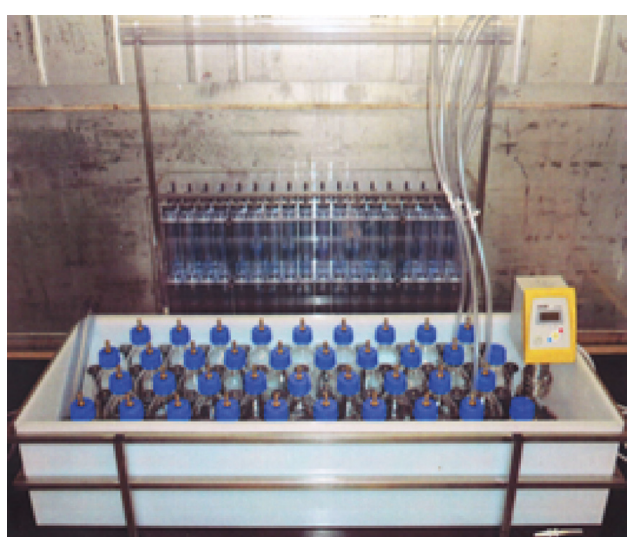

(b)

Figure 1: (a) The biogas reactor. 1: $1 \mathrm{~L}$ glass bottle; 2: connection hose; 3: gas volume; 4: length scale; 5: valve; 6: saturated brine tank; 7: tray. (b) Photograph of the biogas reactor.

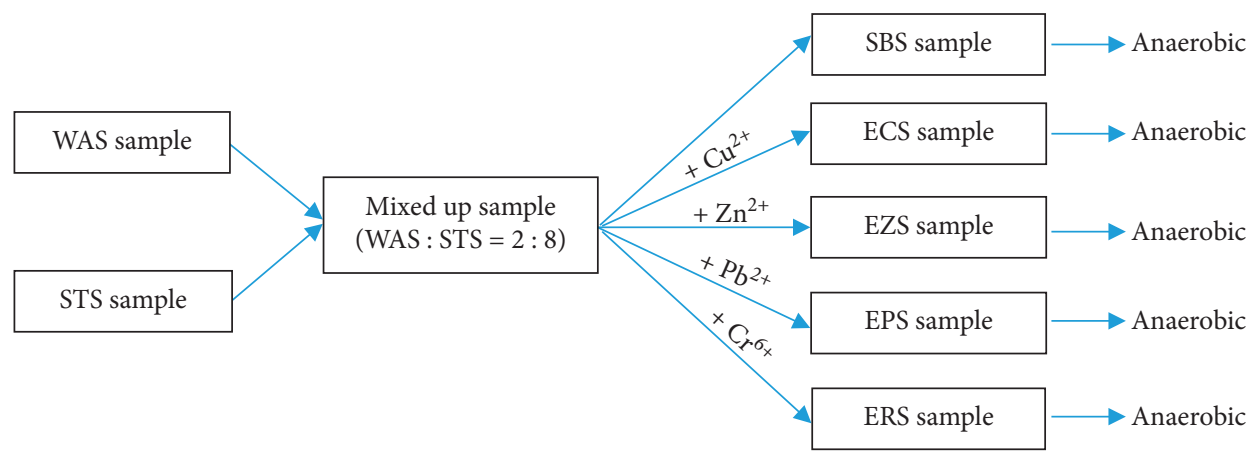

FIGURE 2: Anaerobic digestion flow diagram (SBS: samples without metal addition).

TABLE 1: Sample labels.

\begin{tabular}{lcccc}
\hline \multirow{2}{*}{ Sample } & \multicolumn{4}{c}{ Content } \\
& $19 \mathrm{ppm}$ & $40 \mathrm{ppm}$ & $60 \mathrm{ppm}$ & $80 \mathrm{ppm}$ \\
\hline $\mathrm{Cu}$ & ECS1 & ECS2 & ECS3 & ECS4 \\
$\mathrm{Zn}$ & EZS1 & EZS2 & EZS3 & EZS4 \\
$\mathrm{Pb}$ & EPS1 & EPS2 & EPS3 & EPS4 \\
$\mathrm{Cr}$ & ERS1 & ERS2 & ERS3 & ERS4 \\
\hline
\end{tabular}

respectively. At the higher concentration of $\mathrm{Cu}(\mathrm{II})$, the growth of microorganisms was inhibited; the performance of the anaerobic digestion process decreased, resulting in the reduction of TS and VS. Results of TS and VS analysis of copper metal supplemented samples showed that, at a concentration of $19 \mathrm{ppm}$, anaerobic digestion efficiency decreased sharply with increasing $\mathrm{Cu}$ (II) concentration and the efficiency decreased significantly at $\mathrm{Cu}$ (II) concentration $\geq 40$ ppm, similar to the study of Zayed and Winter [17].

Similarly, the TS and VS removal of zinc metal supplement samples was decreased when the $\mathrm{Zn}$ (II) concentration increased. The EZS4 sample ( $\mathrm{Zn}$ (II) concentration of $80 \mathrm{ppm}$ ) showed the lowest digestion efficiency compared to other samples; the TS and VS were $5.43 \% \pm 0.15 \%$ (removal efficiency was $11.71 \%$ ) and $71.61 \% \pm 1.61 \%$ (removal efficiency was $13.87 \%$ ), respectively. $\mathrm{Zn}$ (II) can make a complex with sludge particles because of a positive charge, leading to precipitate at the bottom of the tank. Therefore, the anaerobic digestion of the microorganism will be reduced, similar to the study of Zayed and Winter [17].

Figure 3 and Table 2 show the TS and VS removal efficiency of the ERS1, ERS2, ERS3, and ERS4 samples and EPS1, EPS2, EPS3, and EPS4 decreased with the increasing of $\mathrm{Cr}, \mathrm{Pb}$ concentration. The ERS4 and EPS4 samples $(\mathrm{Cr}(\mathrm{VI})$ and $\mathrm{Pb}(\mathrm{II})$ concentration $=80 \mathrm{ppm})$ showed a low digestion efficiency compared to other samples. The TS and VS of ERS4 sample were $5.21 \% \pm 0.14 \%$ (removal efficiency $=$ $15.28 \%$ ) and $77.65 \% \pm 1.75 \%$ (removal efficiency $=6.06 \%$ ), respectively. The TS and VS of EPS4 sample were $5.16 \% \pm$ $0.14 \%$ (removal efficiency $=16.10 \%$ ) and $68.46 \% \pm 1.54 \%$ (removal efficiency $=17.66 \%$ ), respectively. The surface of the microorganism was adhered and hindered the metabolism of microorganisms to the process during the anaerobic digestion with the presence of metals [18]. At the higher concentration of metal, the growth of microorganisms was inhibited in the anaerobic digestion, resulting in the reduction of TS and VS. Metal supplemented samples showed a lower TS and VS removal efficiency than the original sample (SBS). 


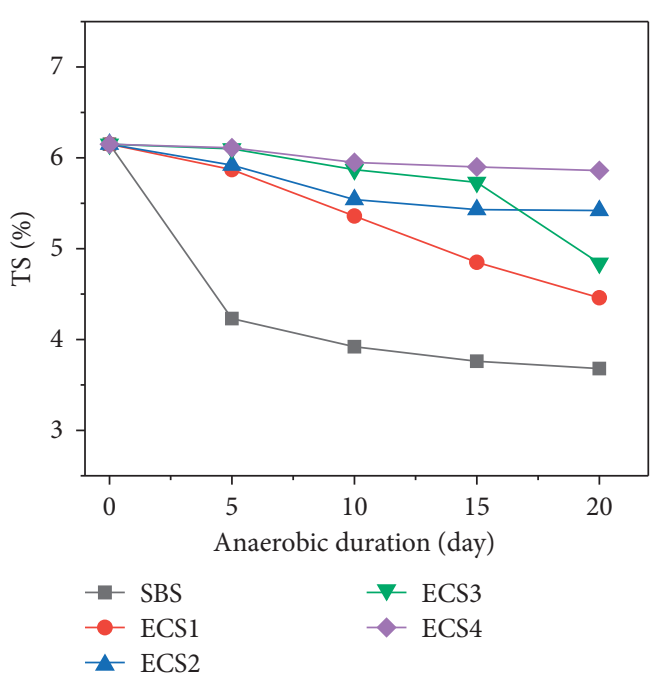

(a)

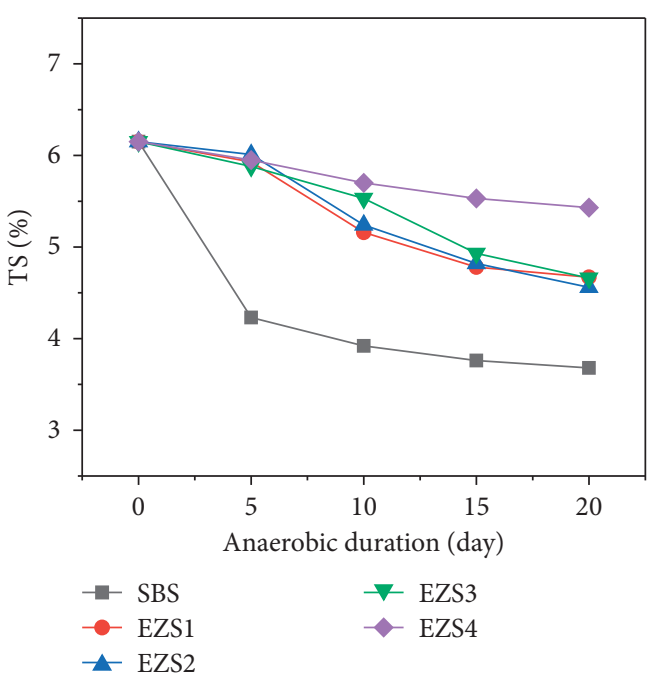

(c)

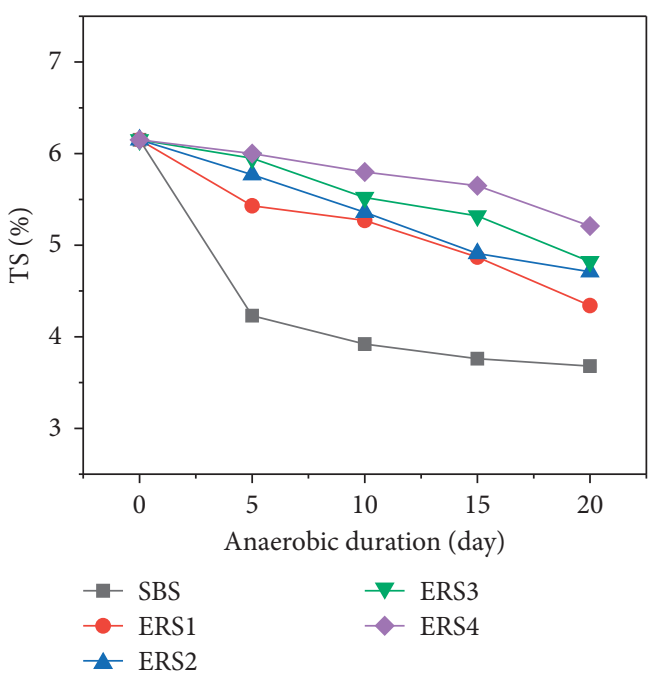

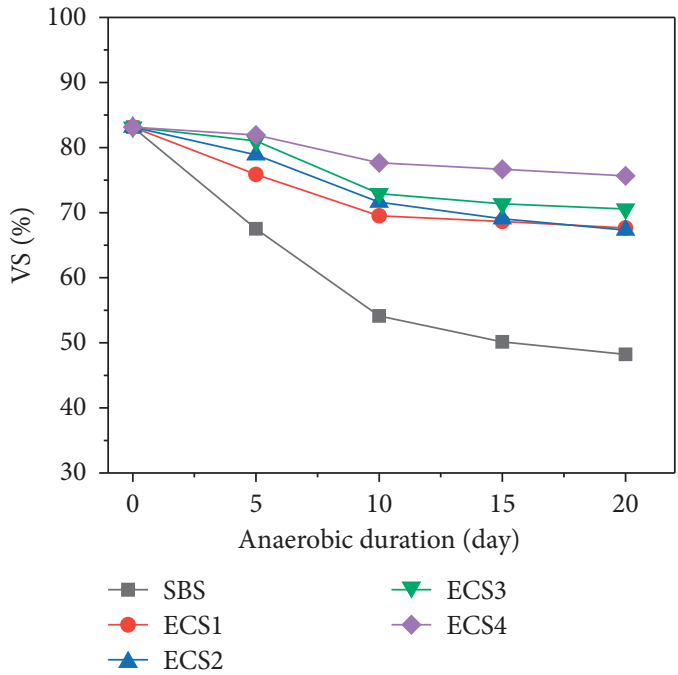

(b)

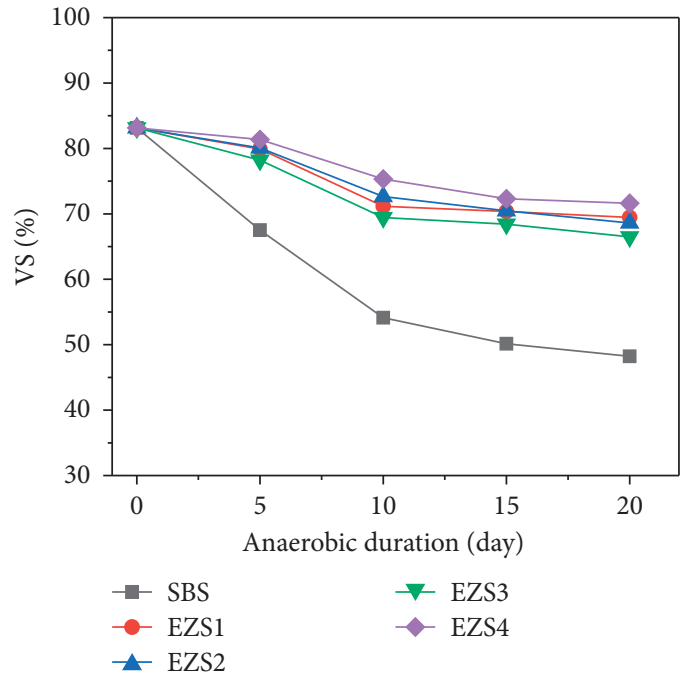

(d)

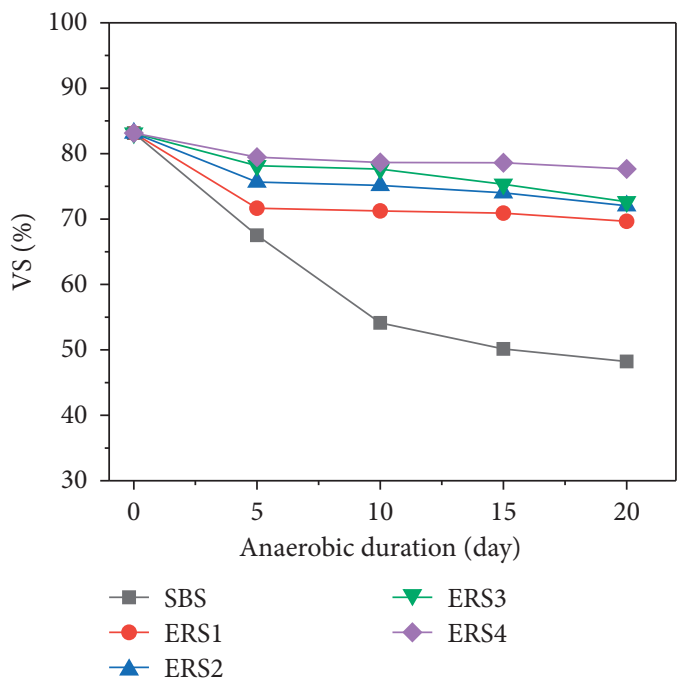

(f)

Figure 3: Continued. 


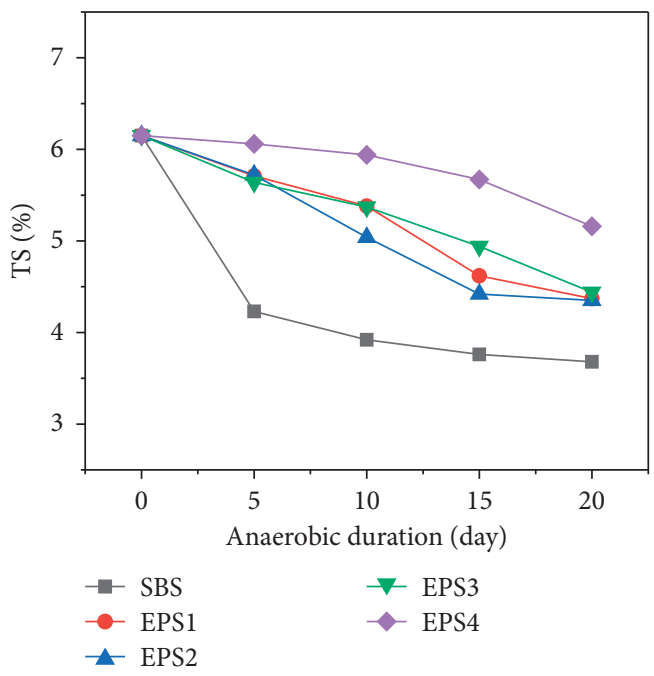

(g)

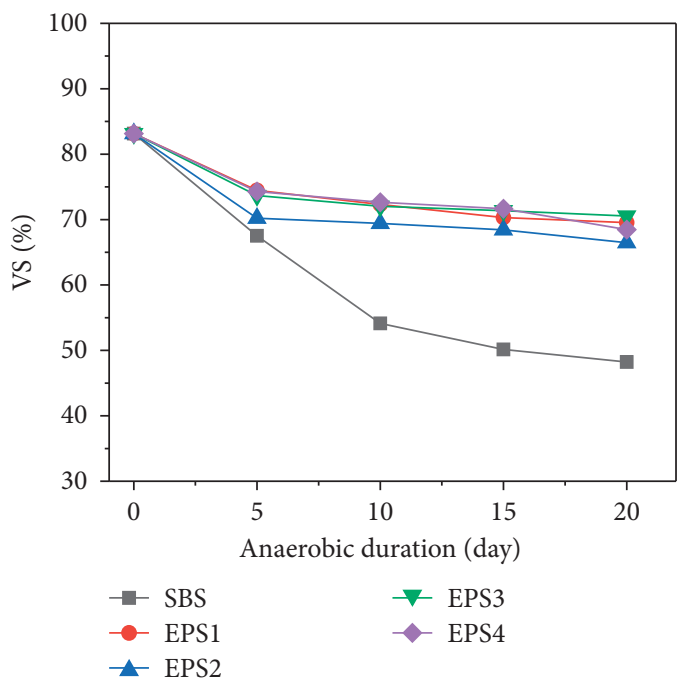

(h)

Figure 3: Total solids and volatile solid of samples.

TABLE 2: TS and VS removal performance during digestion (\%).

\begin{tabular}{|c|c|c|c|c|c|c|c|c|c|c|}
\hline \multirow{2}{*}{ Day } & TS & VS & TS & VS & TS & VS & TS & VS & TS & VS \\
\hline & \multicolumn{2}{|c|}{ SBS } & \multicolumn{2}{|c|}{ ECS1 } & \multicolumn{2}{|c|}{ ECS2 } & \multicolumn{2}{|c|}{ ECS3 } & \multicolumn{2}{|c|}{ ECS4 } \\
\hline 5 & 31.22 & 18.80 & 4.55 & 8.73 & 3.74 & 5.12 & 0.81 & 2.54 & 0.65 & 1.46 \\
\hline 10 & 24.88 & 34.90 & 12.85 & 16.38 & 9.92 & 13.86 & 4.55 & 12.28 & 3.25 & 6.59 \\
\hline 15 & 30.73 & 39.69 & 21.14 & 17.43 & 11.71 & 16.94 & 6.83 & 14.17 & 4.07 & 7.79 \\
\hline \multirow[t]{2}{*}{20} & 34.63 & 41.99 & 27.48 & 18.62 & 11.87 & 19.03 & 21.30 & 15.13 & 4.72 & 9.01 \\
\hline & \multicolumn{2}{|c|}{ SBS } & \multicolumn{2}{|c|}{ EZS1 } & \multicolumn{2}{|c|}{ EZS2 } & \multicolumn{2}{|c|}{ EZS3 } & \multicolumn{2}{|c|}{ EZS4 } \\
\hline 5 & 31.22 & 18.80 & 3.58 & 3.89 & 2.28 & 3.69 & 4.39 & 5.93 & 3.25 & 2.13 \\
\hline 10 & 24.88 & 34.90 & 16.10 & 14.41 & 14.80 & 12.62 & 10.08 & 16.49 & 7.32 & 9.41 \\
\hline 15 & 30.73 & 39.69 & 22.28 & 15.37 & 21.63 & 15.25 & 19.84 & 17.69 & 10.08 & 13.03 \\
\hline \multirow[t]{2}{*}{20} & 34.63 & 41.99 & 24.07 & 16.45 & 25.85 & 17.48 & 24.23 & 20.04 & 11.71 & 13.87 \\
\hline & \multicolumn{2}{|c|}{ SBS } & \multicolumn{2}{|c|}{ ERS1 } & \multicolumn{2}{|c|}{ ERS2 } & \multicolumn{2}{|c|}{ ERS3 } & \multicolumn{2}{|c|}{ ERS4 } \\
\hline 5 & 31.22 & 18.80 & 11.71 & 13.82 & 6.18 & 9.01 & 3.25 & 5.99 & 2.44 & 4.43 \\
\hline 10 & 24.88 & 34.90 & 14.31 & 14.31 & 12.85 & 9.62 & 10.24 & 6.63 & 5.69 & 5.41 \\
\hline 15 & 30.73 & 39.69 & 20.81 & 14.71 & 20.16 & 10.97 & 13.50 & 9.42 & 8.13 & 5.45 \\
\hline \multirow[t]{2}{*}{20} & 34.63 & 41.99 & 29.43 & 16.23 & 23.41 & 13.36 & 21.63 & 12.62 & 15.28 & 6.60 \\
\hline & \multicolumn{2}{|c|}{ SBS } & \multicolumn{2}{|c|}{ EPS1 } & \multicolumn{2}{|c|}{ EPS2 } & \multicolumn{2}{|c|}{ EPS3 } & \multicolumn{2}{|c|}{ EPS4 } \\
\hline 5 & 31.22 & 18.80 & 7.15 & 10.43 & 6.99 & 15.55 & 8.29 & 11.38 & 1.46 & 10.66 \\
\hline 10 & 24.88 & 34.90 & 12.52 & 13.03 & 18.05 & 16.50 & 12.68 & 13.36 & 3.41 & 12.62 \\
\hline 15 & 30.73 & 39.69 & 24.88 & 15.43 & 28.13 & 17.69 & 19.67 & 14.18 & 7.80 & 13.82 \\
\hline 20 & 34.63 & 41.99 & 28.94 & 16.36 & 29.27 & 20.05 & 27.80 & 15.14 & 16.10 & 17.66 \\
\hline
\end{tabular}

The metal supplementation reduced the ability to remove TS and VS or reduced the ability to decompose organic volatile matter. Metals supplementation showed TS and VS removal efficiency compared with $\mathrm{Zn}, \mathrm{Pb}, \mathrm{Cd}$, and $\mathrm{Cu}$; their toxicity grows as an order of $\mathrm{Pb}<\mathrm{Cr}<\mathrm{Zn}<\mathrm{Cu}$, depending on numerous biotic and abiotic factors, and the higher the metal concentration, the greater the effect on the process. In case $\mathrm{Cu}$ exhibited the highest toxicity, this may be due to the affinity of $\mathrm{Cu}$ with organically/sulfide bound fraction [19]. Therefore, at higher metal concentration, the inhibition of the growth of microorganisms during anaerobic digestion would be increased.
3.2. Effects of Copper, Lead, Chromium, and Zinc for COD Removal. The speed and ability of COD removal were closely related to the ability of producing biogas in the anaerobic co-digestion process. Through these measurements, it is possible to assess microbial activity and thereby evaluate the overall activity of anaerobic digestion based on the effects of $\mathrm{Cu}(\mathrm{II}), \mathrm{Zn}(\mathrm{II}), \mathrm{Cr}(\mathrm{VI})$, and $\mathrm{Pb}(\mathrm{II})$ into the digestion mixture. During monitoring and analysis with a sampling frequency of 05 days, the results of COD analysis over time are shown in Figure 4.

Figure 4 shows that the COD of the samples decreased with the anaerobic process time. During the first 5 days of 


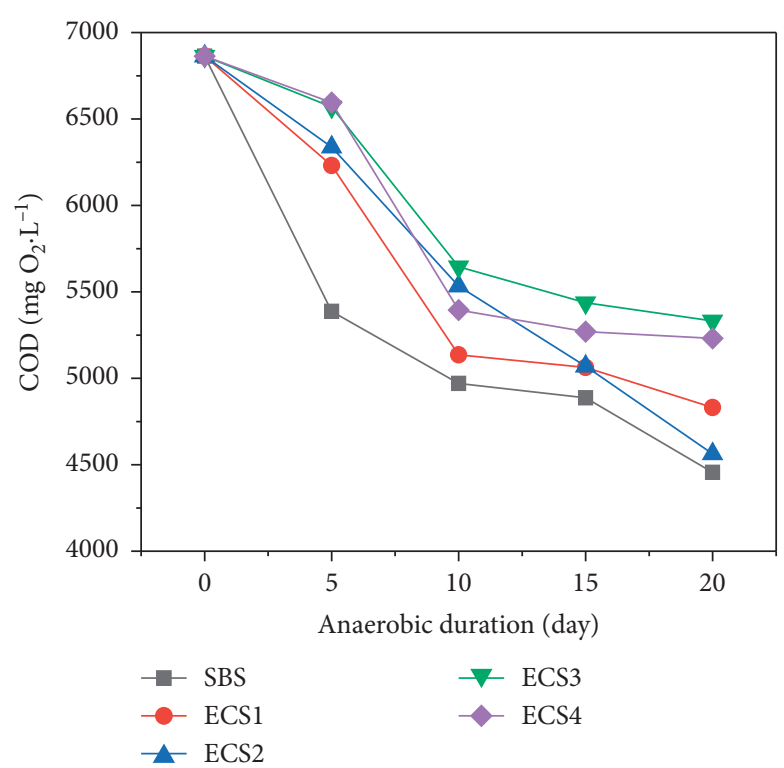

(a)

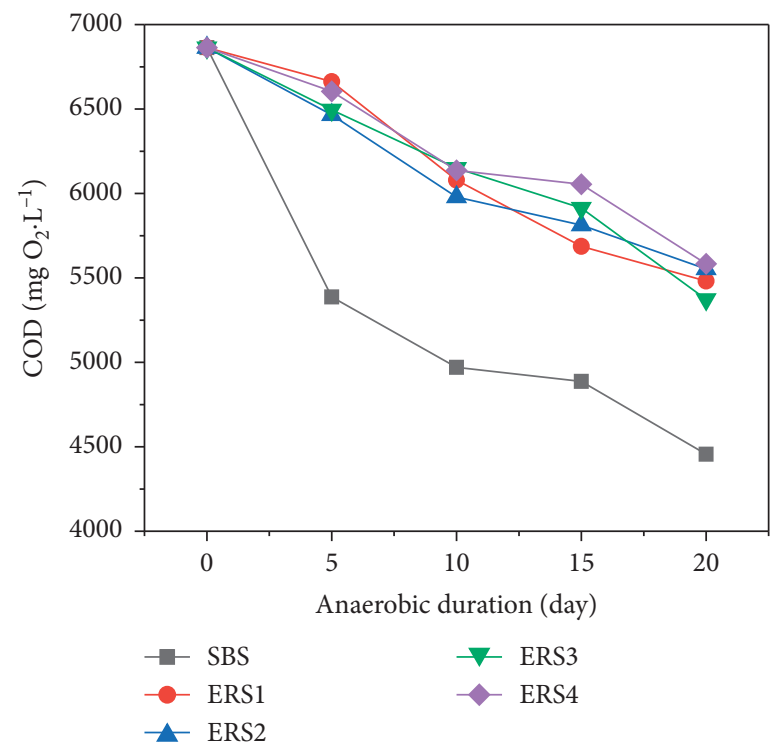

(c)

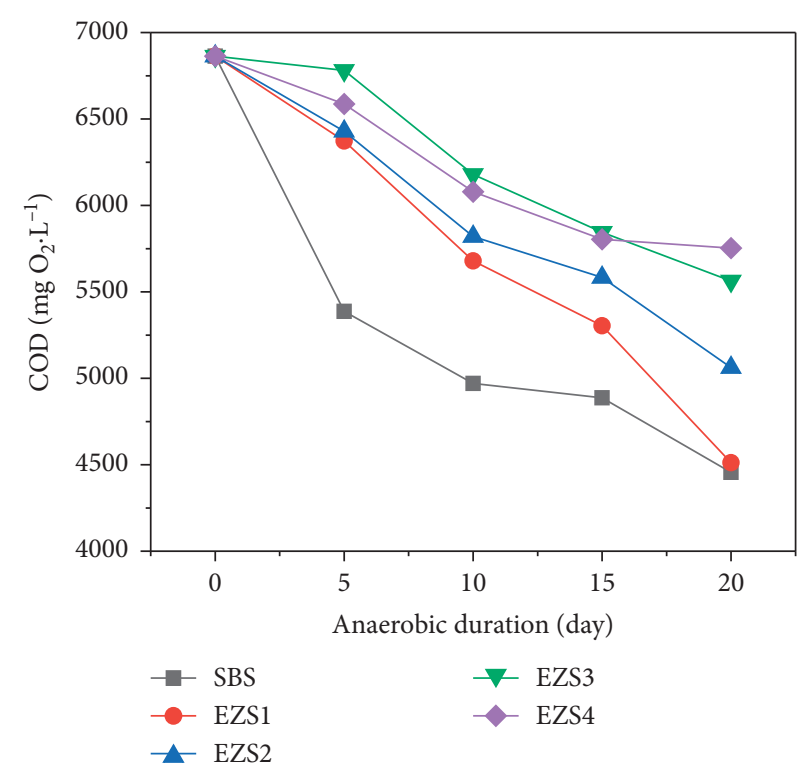

(b)

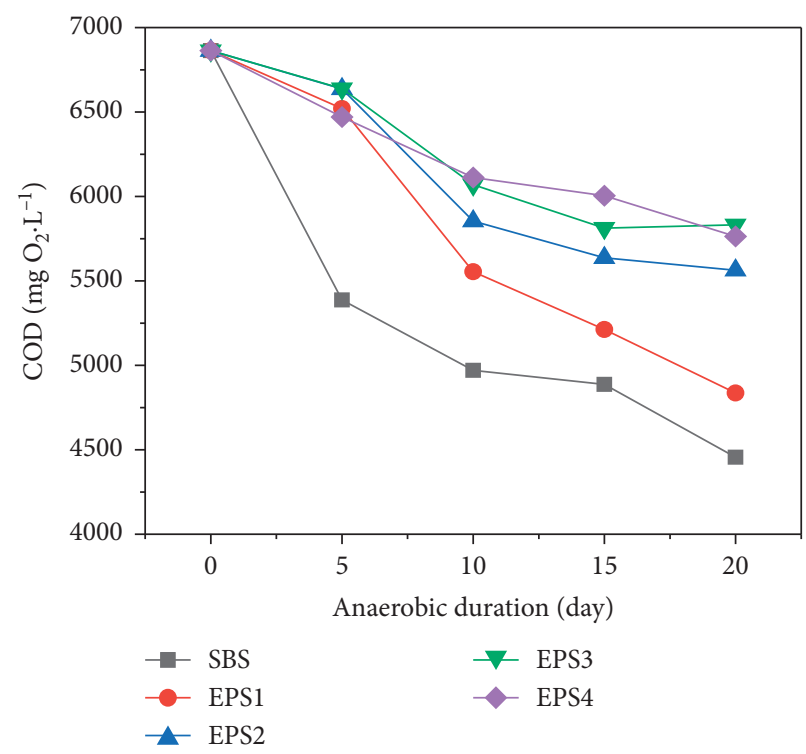

(d)

FIgURE 4: COD removal during anaerobic digestion without and with the presence of copper, zinc, chromium, and lead.

digestion, the COD of the SBS sample sharply decreased (21.51\%) while samples with metal supplementation showed ability of a low COD removal, which were ECS4 samples (3.9\% reduction), EZS3 (1.9\% reduction), ERS4 (3.77\% reduction), and EPS3 (3.28\% reduction), respectively. Digestion time in the next five days of the sample showed COD reduction; the samples that slowly reduced were as follows: ECS4 6.51\%, EZS3 9.96\%, ERS3 10.40\%, and EPS4 10.94\%, respectively. Then, the reduced COD removal ability showed low organic content in the sludge. In addition, the composition of highly biodegradable organic substances reduced the microbial activity of the organism. Inefficient microbial activity leads to the inefficient stabilization of persistent organic compounds that need to be removed.
The toxicity of $\mathrm{Cu}(\mathrm{II})$ and $\mathrm{Zn}(\mathrm{II})$ is due to the disruption of enzyme function and structure by binding metal ions to thiol and other groups on protein molecules or by substituting natural metals in fake enzyme groups. Enzymes of the microorganism make them more likely to grow and the biomass weakens, resulting in a weakened COD. Fang and Hui [20] found that heavy metals inhibit the activity of $\mathrm{CH}_{4}$ microorganisms of starch granules during anaerobic digestion.

After 20 days of digestion, the initial sample had the highest COD removal efficiency (down from $6863 \pm 46 \mathrm{mg}$ $\mathrm{O}_{2} \cdot \mathrm{L}^{-1}$ to $4456 \pm 30 \mathrm{mg} \mathrm{O} \cdot \mathrm{L}^{-1}$ with removal efficiency $=$ $35.44 \%$ ), while the COD removal efficiency of the metaladded samples was less than the SBS sample. This indicates 


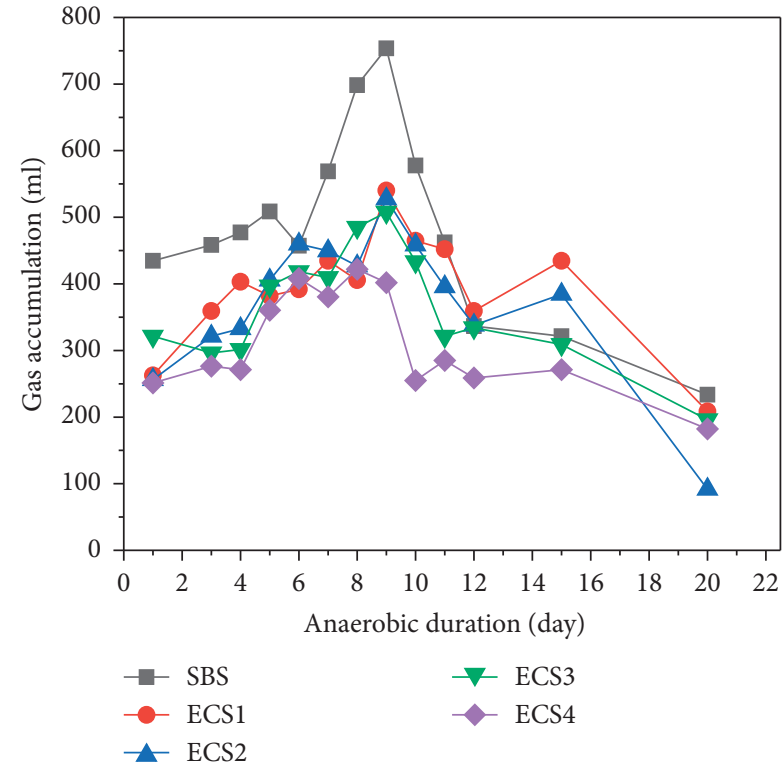

(a)

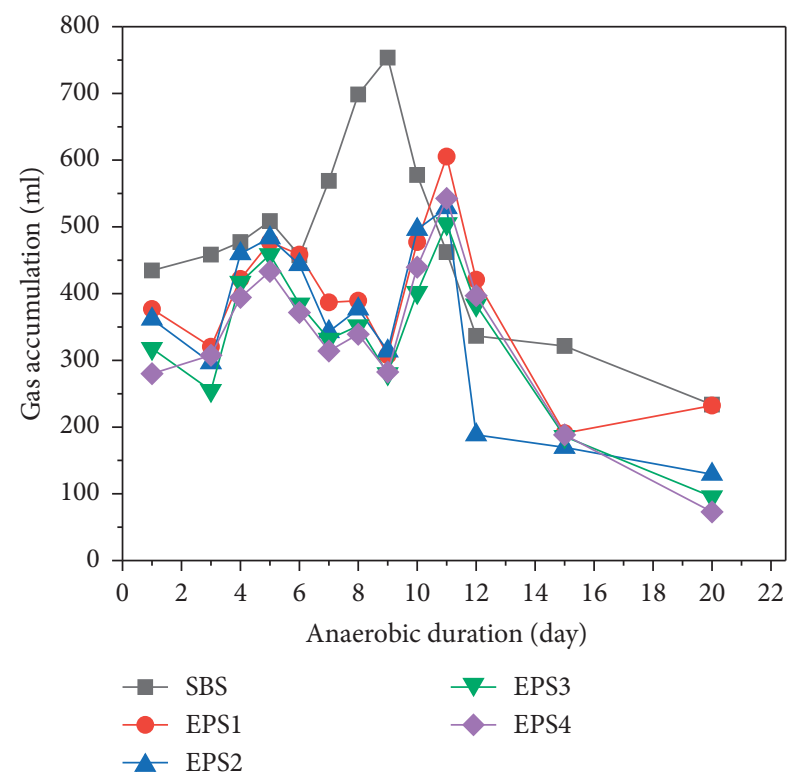

(c)

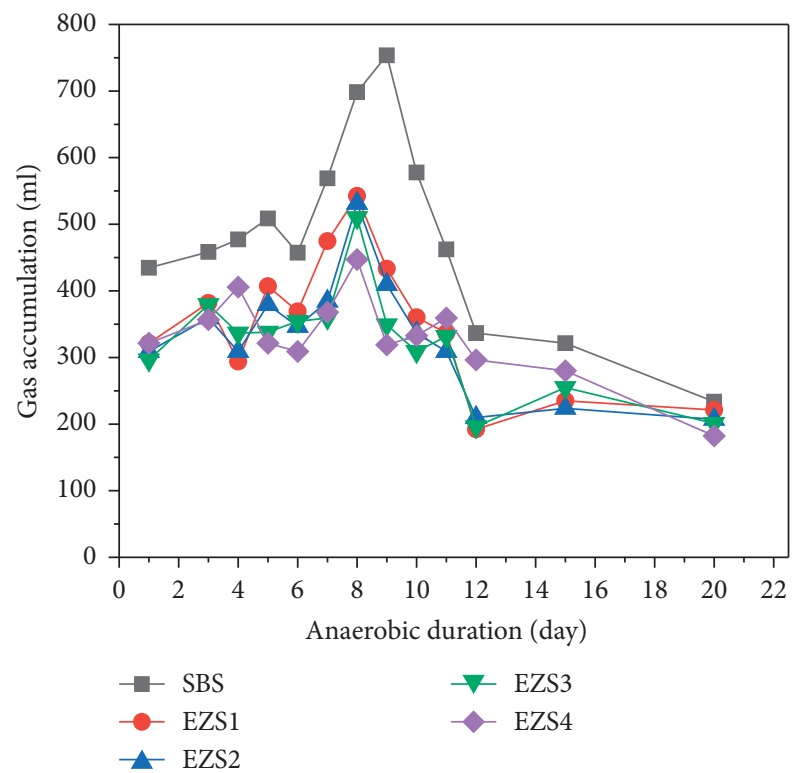

(b)

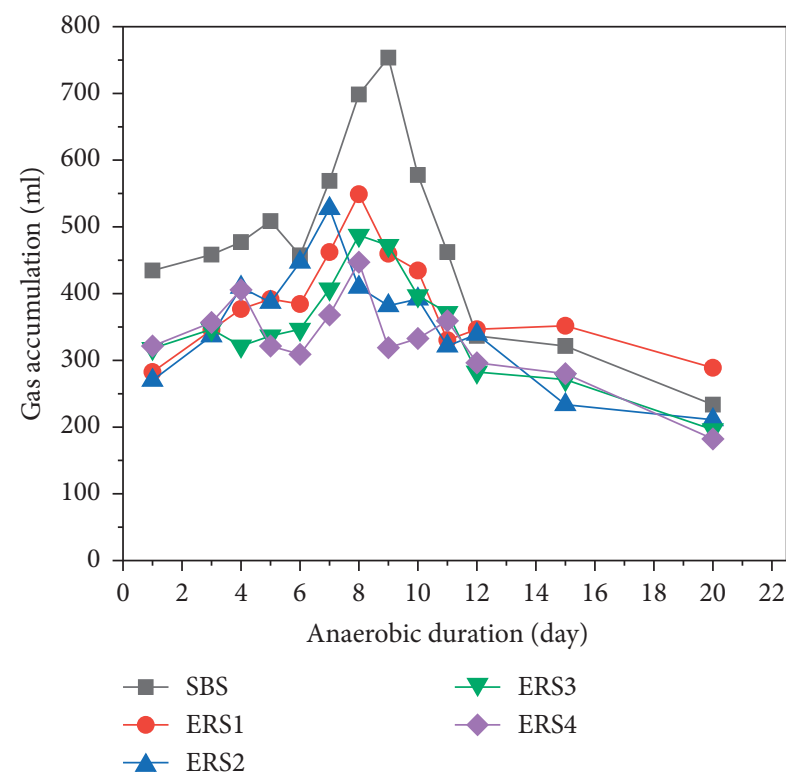

(d)

FIGURE 5: Effect of copper, zinc, chromium, and lead on biogas volume generated during the digestion.

that metal ions act on the digestion mixture by reducing the COD removal capacity of the mixture, preventing the breakdown of organic compounds or inhibiting microbial growth.

\subsection{Effects of Copper, Lead, Chromium, and Zinc for Biogas} Generation. Normally, when decomposing $1 \mathrm{~kg}$ of dry organic matter, about $0.2-1.11 \mathrm{~m}^{3}$ of biogas was collected [21]. However, the amount of biogas produced was strongly affected by many factors of anaerobic fermentation. Figure 5 depicts biogas production in experiments with initial mixed sludge samples and supplemented metal samples. The results from experiments showed that there were always two vertices of maximum gas. This phenomenon demonstrated that biogas production was related to the digestion of organic compounds contained in the input materials. The first strong gas-phase corresponded to the digestion of the decomposing organic compounds and the second weaker phase showed the digestion of the persistent organic compounds when it took sufficient time for microorganisms to adapt and dissolve systematically.

The volume of gas generated was the most from 8 to 10 days with the SBS sample. The samples with supplementation of metals having the time of the gas generated were the most from the $10^{\text {th }}$ day; then the samples were gradually 
reduced in gas volume. The graph showed the maximum amount of gas produced by the SBS sample $(6210 \pm 56 \mathrm{ml})$, while the samples' supplementation of $\mathrm{Cu}(\mathrm{II})$ was as follows: ECS1, ECS2, ECS3, and ECS4 being $5098 \pm 43 \mathrm{ml}$, $4848 \pm 37 \mathrm{ml}, 4730 \pm 42 \mathrm{ml}$, and $4024 \pm 24 \mathrm{ml}$, respectively. It can be seen that the higher the amount of the added $\mathrm{Cu}(\mathrm{II})$, the less the produced amount of gas (less than 27\% compared to the SBS sample).

It could be concluded that when the concentration of heavy metals in digestion is $80 \mathrm{ppm}$, the biogas yields can be decreased by $36.33 \%, 31.64 \%, 31.64 \%$, and $30.62 \%$ with $\mathrm{Cu}(\mathrm{II}), \mathrm{Zn}(\mathrm{II}), \mathrm{Cr}(\mathrm{VI})$, and $\mathrm{Pb}(\mathrm{II})$, respectively, compared with the SBS sample.

\section{Conclusion}

The presence of heavy metals such as copper, lead, chromium, and zinc in the mixture of waste activated sludge and septic tank sludge decreased the efficiency of the anaerobic co-digestion process. A significant decrease in TS, VS, and COD removal and biogas generation was determined. Effect of $\mathrm{Cu}$ (II) inhibits the anaerobic digestion of the sludge mixture more strongly than that of $\mathrm{Zn}(\mathrm{II}), \mathrm{Cr}(\mathrm{VI})$, and $\mathrm{Pb}(\mathrm{II})$. The relative toxicity to the co-digestion process of waste activated sludge and septic tank sludge was found in the following order: $\mathrm{Cu}$ (the most toxic) $>\mathrm{Zn}>\mathrm{Cr}>\mathrm{Pb}$ (the least toxic). Therefore, it is recommended that the presence of toxic heavy metals such as $\mathrm{Cu}, \mathrm{Zn}, \mathrm{Cr}$, and $\mathrm{Pb}$ in municipal sludge should be controlled in the anaerobic codigestion system for the biogas production, as well as the safety of the land application.

\section{Data Availability}

The data used to support the findings of this study are available from the corresponding author upon request.

\section{Conflicts of Interest}

The authors declare that they have no conflicts of interest.

\section{Acknowledgments}

This research is funded by the Vietnam National University, Hanoi (VNU), under Project Number QG.17.25. The authors also wish to thank Kim Lien Wastewater Treatment Plant and Urenco 7 Company for providing samples of sludge.

\section{References}

[1] A. Mudhoo and S. Kumar, "Effects of heavy metals as stress factors on anaerobic digestion processes and biogas production from biomass," International Journal of Environmental Science and Technology, vol. 10, no. 6, pp. 1383-1398, 2013.

[2] M. L. Workentine, J. J. Harrison, P. U. Stenroos, H. Ceri, and R. J. Turner, "Pseudomonas fluorescens' view of the periodic table," Environmental Microbiology, vol. 10, no. 1, pp. 238250,2008 .
[3] R. Reza and G. Singh, "Heavy metal contamination and its indexing approach for river water," International Journal of Environmental Science and Technology, vol. 7, no. 4, pp. 785-792, 2010.

[4] Nguyen Thi Thuong, M. Yoneda, M. Ikegami, and T. Masato, "Source discrimination of heavy metals in sediment and water of to Lich River in Hanoi City using multivariate statistical approaches," Environmental Monitoring and Assessment, vol. 185, no. 10, pp. 8065-8075, 2013.

[5] J. L. Chen, R. Ortiz, T. W. J. Steele, and D. C. Stuckey, "Toxicants inhibiting anaerobic digestion: a review," Biotechnology Advances, vol. 32, no. 8, pp. 1523-1534, 2014.

[6] C. Li and H. H. P. Fang, "Inhibition of heavy metals on fermentative hydrogen production by granular sludge," Chemosphere, vol. 67, no. 4, pp. 668-673, 2007.

[7] Y. Chen, J. J. Cheng, and K. S. Creamer, "Inhibition of anaerobic digestion process: a review," Bioresource Technology, vol. 99, no. 10, pp. 4044-4064, 2008.

[8] H. He, Y. Tian, H. Zhang, and Y. Chai, "Copper stressed anaerobic fermentation: biogas properties, process stability, biodegradation and enzyme responses," Biodegradation, vol. 28, no. 5-6, pp. 369-381, 2017.

[9] L. Appels, J. Baeyens, J. Degrève, and R. Dewil, "Principles and potential of the anaerobic digestion of waste-activated sludge," Progress in Energy and Combustion Science, vol. 34, no. 6, pp. 755-781, 2008.

[10] L. Altaş, "Inhibitory effect of heavy metals on methaneproducing anaerobic granular sludge," Journal of Hazardous Materials, vol. 162, no. 2-3, pp. 1551-1556, 2009.

[11] M. Sarioglu, S. Akkoyun, and T. Bisgin, "Inhibition effects of heavy metals (copper, nickel, zinc, lead) on anaerobic sludge," Desalination \& Water Treatment, vol. 23, no. 1-3, pp. 55-60, 2010.

[12] H. I. Abdel-Shafy and M. S. M. Mansour, "Biogas production as affected by heavy metals in the anaerobic digestion of sludge," Egyptian Journal of Petroleum, vol. 23, no. 4, pp. 409-417, 2014.

[13] B. A. Parra-Orobio, P. Torres-Lozada, and L. F. MarmolejoRebellón, "Influence of the mixing ratio on the anaerobic codigestion of municipal biowaste with domestic wastewater sludge on methane production," DYNA, vol. 83, no. 199, pp. 86-93, 2016.

[14] W. C. Kuo-Dahab, P. Amirhor, Z. Meredith, D. Duest, and C. Park, Investigating Anaerobic Co-digestion of Sewage Sludge and Food Waste Using a Bench-Scale Pilot Study, Water Environment Federation, no. 21, VA, USA, 2014.

[15] Y. H. Feng, Y. B. Zhang, X. Quan, and S. Chen, "Enhanced anaerobic digestion of waste activated sludge digestion by the addition of zero valent iron," Water Research, vol. 52, pp. 242-250, 2014.

[16] D. Bolzonella, P. Pavan, M. Zanette, and F. Cecchi, "Twophase anaerobic digestion of waste activated sludge: effect of an extreme thermophilic prefermentation," Industrial \& Engineering Chemistry Research, vol. 46, no. 21, pp. 66506655, 2007.

[17] G. Zayed and J. Winter, "Inhibition of methane production from whey by heavy metals-protective effect of sulfide," Applied Microbiology and Biotechnology, vol. 53, no. 6, pp. 726-731, 2000.

[18] G. M. Figueroa-Torres, M. T. Certucha-Barragán, F. J. Almendariz-Tapia et al., "Effect of copper and iron on acidogenic biomass in an anaerobic packed bed reactor," Advances in Bioscience and Biotechnology, vol. 5, no. 6, 2014. 
[19] B. Q. Icela, S. P. Mónica, and G. A. Julisa, "Performance of an UASB reactor at lab-scale treating domestic wastewater with low concentrations of copper," British Journal of Applied Science \& Technology, vol. 7, p. 456, 2015.

[20] H. H. P. Fang and H. H. Hui, "Effect of heavy metals on the methanogenic activity of starch-degrading granules," Biotechnology Letters, vol. 16, no. 10, pp. 1091-1096, 1994.

[21] P. Chongrak, Organic Waste Recycling, Wiley, Hoboken, NJ, USA, 1996. 


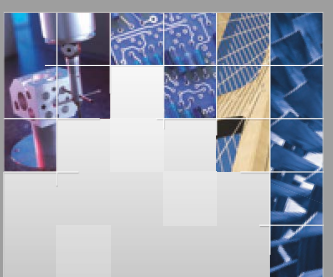

\section{Enfincering}
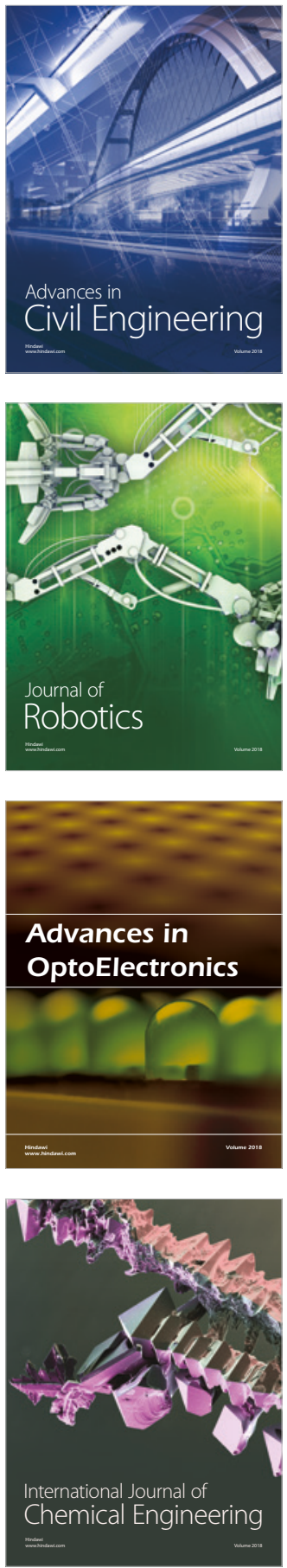

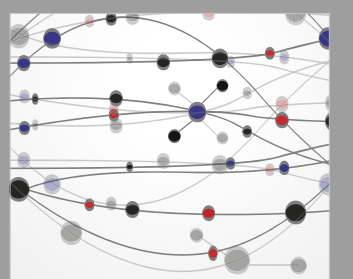

\section{Rotating \\ Machinery}

The Scientific World Journal

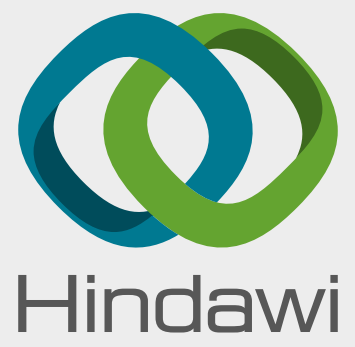

Submit your manuscripts at

www.hindawi.com
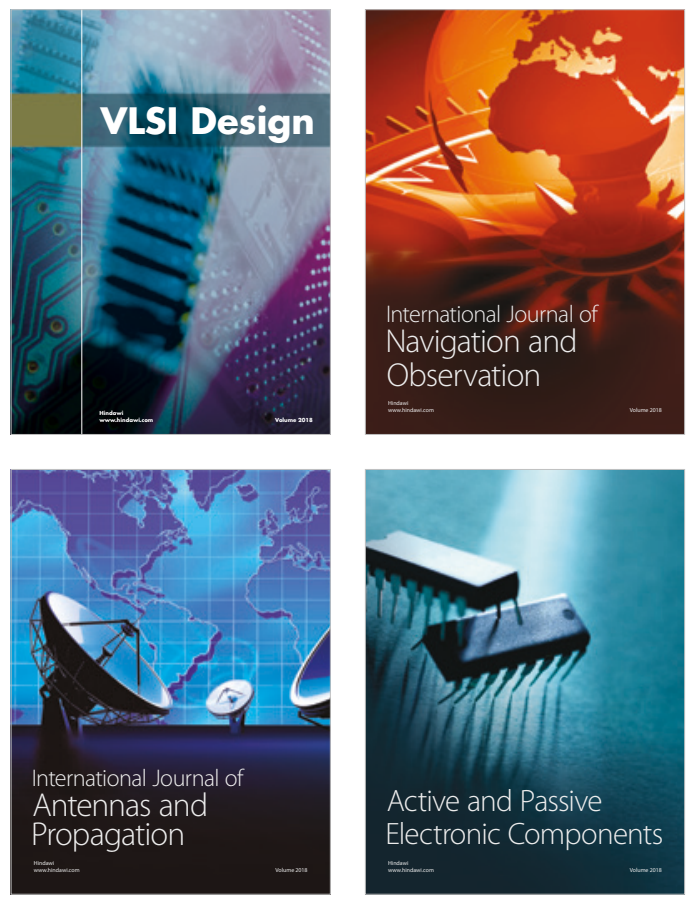
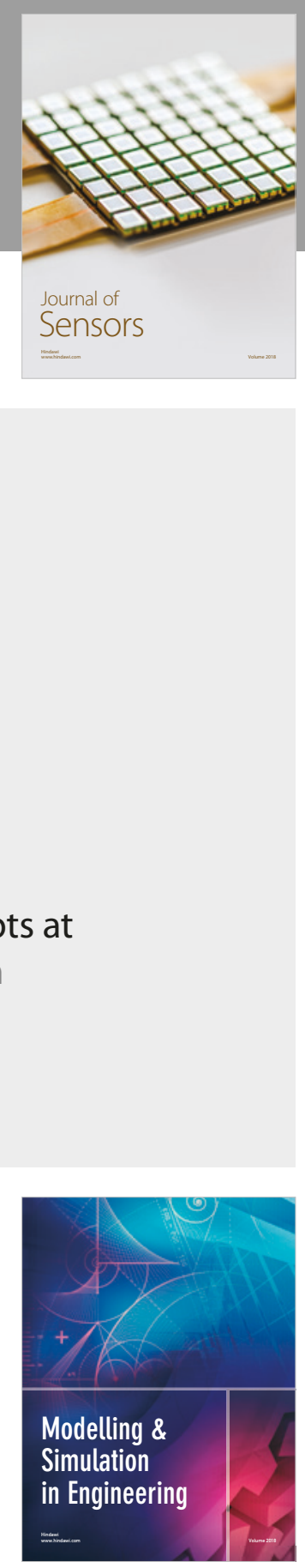

\section{Advances \\ Multimedia}
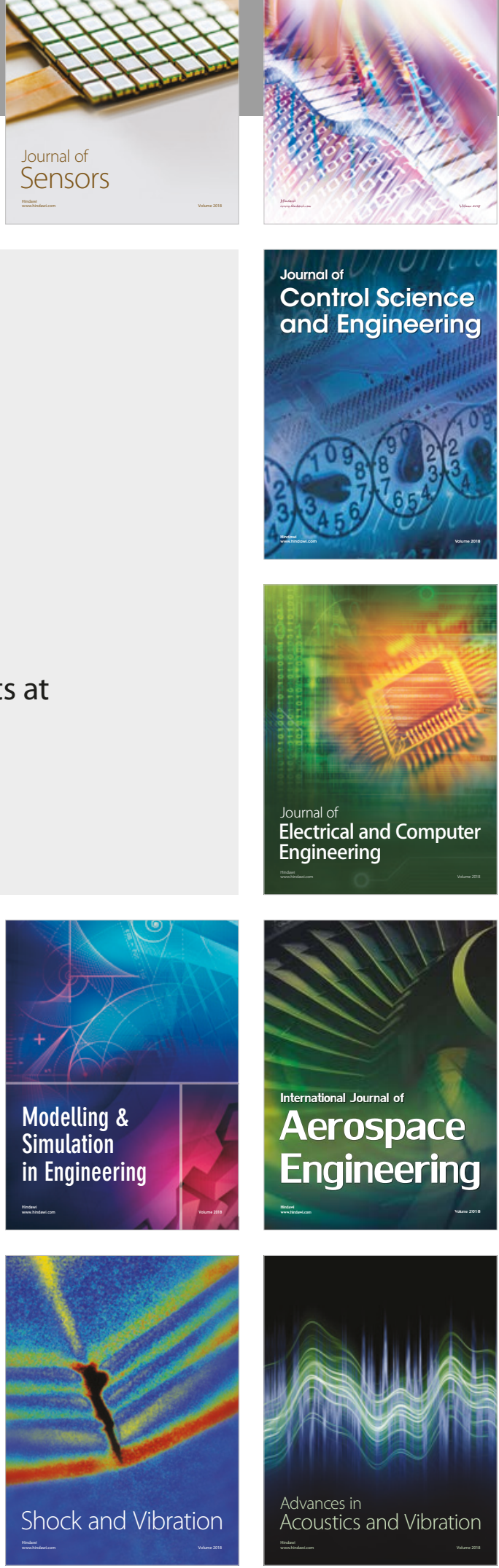